УДК:657.1:330.34:631.95

JEL Classification: Q01, M40, C50

О. Г. СОКІЛ,

кандидат економічних наук, доцент кафедри обліку і оподаткування,

Таврійський державний агротехнологічний університет

\title{
Методологічна основа обліково-аналітичного забезпечення формування звітності сільськогосподарських підприємств про сталий розвиток
}

У статті проаналізовано світові тендениії підготовки звітності з корпоративної відповідальності сільськогосподарськими підприємствами. Запропоновано три варіанти звітів про сталий розвиток сільськогосподарського підприємства: звіт про сталий розвиток; альтернативний звіт; розширений фінансовий звіт. Розроблено матрицю оиінки рівня обліково-аналітичного забезпечення сталого розвитку сільськогосподарського підприємства, яка ілюструє вплив (сильний, суттєвий, незначний, відсутній) десяти аспектів сталого розвитку на рівень обліково-аналітичного забезпечення прочесу формування фінансових результатів та їх відображення у звітності про сталий розвиток. Побудовано дерево рішень для визначення варіантів звітності про сталий розвиток залежно від розміру сільськогосподарських підприємств, їх самоідентифікації і усвідомлення впливу на еко-сочіальне середовище.

Ключові слова: обліково-аналітичне забезпечення, звітність про сталий розвиток, звіт про сталий розвиток, сільськогосподарське підприємство, нефінансова звітність, зацікавлені сторони.

Постанова проблеми. Зважаючи на посилення тренду використання звітності 3 розкриттям інформації про сталий розвиток у світі зростає попит на звіти про сталий розвиток у сільському господарстві. Проблематика дослідження обліково-аналітичного забезпечення звітності сільськогосподарських підприємств про сталий розвиток характеризується важливими аспектами, пов'язаними з обліком сталого розвитку, такими як концепція обліку розвитку навколишнього середовища, характер звітів про управління сталим розвитком, потреби зацікавлених осіб у звітах про сталий розвиток, інформаційний контент звітів про сталий розвиток, напрями та шляхи оприлюднення корпоративної звітності про сталий розвиток, роль бухгалтерів у забезпеченні корпоративної соціальної відповідальності як фактора сталого розвитку, професійні й облікові стандарти формування звітності з корпоративної відповідальності в розрізі економічної, екологічної та соціальної діяльності. Правила та норми формування звітності про сталий розвиток у сільському господарстві $\epsilon$ на сьогодні найменш регламентованими, що обумовлює актуальність методологічних досліджень обліковоаналітичного забезпечення звітності сільськогосподарських підприємств про сталий розвиток.

Аналіз останніх досліджень і публікацій. Проблемним аспектам обліковоаналітичного забезпечення формування звітності про сталий розвиток та шляхам вдосконалення його методологічних основ присвячені праці багатьох вітчизняних учених, серед яких С. Король, С. Свірко, О. Баришнікова, О. Романенко, О. Комірна, Р. Мацьків, А. Колот, О. Гриценко, Т. Довга, В. Воробей, І. Журовська, О. Хамідова, А. Хамідова та інші.

Незважаючи на значну кількість публікацій за цією тематикою, проблеми обліково-аналітичного забезпечення формування звітності сталого розвитку сільськогосподарських підприємств залишаються повністю невирішеними.

Метою статті є узагальнення теоретичних аспектів та розроблення методологічноӥ основи обліково-аналітичного забезпечення формування звітності сільськогосподарських підприємств про сталий розвиток.

(C) О. Г. Сокіл, 2018 
Виклад основного матеріалу дослідження. Корпоративна звітність про сталий розвиток є предметом широких досліджень в останні десятиліття, здобутком яких є визначення корпоративного звіту про сталий розвиток як публічного звіту компанії для надання внутрішнім і зовнішнім зацікавленим сторонам уявлення про економічні, екологічні та соціальні аспекти їі діяльності. Початок 90-х років у світі ознаменувався формуванням звітів про сталий розвиток великими підприємствами, а у новому тисячолітті (з 2001 року) підвищився рівень розкриття не тільки економічної, а й екологічної та соціальної інформації в Англії, Японії та Німеччині. У 2002 році опубліковано перші принципи розкриття інформації у звітах про сталий розвиток 3 їх подальшим переглядом й оприлюдненням у 2006 році як основи для складання звіту $[1$, c. 1$]$.

У 2016 році близько 5000 компаній світу подали звіти про сталий розвиток, складені на основі стандартів GRI (Global Reporting Initiative), 3 яких лише 20 українські [2]. Дослідження практики опублікування нефінансових звітів в Україні за 2016 рік дозволило встановити, що питома вага звітів із прогресу складає 91,5\%, а звітів за GRI-стандартом - лише 8,5\%. Тобто перевага надається звітам, які не підлягають обов'язковому аудиту і не потребують верифікації. Наведені показники свідчать:

- по-перше, про відсутність теоретичного обгрунтування нефінансових звітів й практичного досвіду їх складання в переважної більшості вітчизняних підприємств;

- по-друге, нерозуміння переваг “стандартизованих" звітів [3, с. 105].

В Україні підготовка нефінансових звітів все ще $є$ прерогативою великих національних компаній та представництв міжнародних корпорацій. Але спостерігається і позитивна динаміка: так, у 2016 році впроваджувати звіти з використанням стандартів GRI почали великі державні підприємства [2]. Сільськогосподарські виробники впроваджують не лише передові технології виробництва та управління, а й прогресивні методи звітності з огляду на зацікавленість у вільному доступі до прозорої інформації як інвесторів та кредиторів, так і співробітників підприємств й суспільства в цілому.

Зважаючи на зростання попиту на звіти про сталий розвиток у сільському господарстві у 2016 році 190 сільськогосподарських виробників з різних країн світу підготували звітність 3 корпоративної відповідальності (табл. 1).

Таблиия 1

Сільськогосподарські підприємства світу, що готують нефінансову звітність, станом на 2016 рік

\begin{tabular}{|c|l|c|c|c|c|c|c|c|}
\hline \multirow{2}{*}{$\begin{array}{c}\text { № } \\
3 / \text { п }\end{array}$} & $\begin{array}{c}\text { Регіон } / \\
\text { країна }\end{array}$ & $\begin{array}{c}\text { Зага- } \\
\text { лом }\end{array}$ & $\begin{array}{c}\text { За стандар- } \\
\text { тами GRI }\end{array}$ & $\begin{array}{c}\text { За іншими } \\
\text { стандарта- } \\
\text { ми }\end{array}$ & $\begin{array}{c}\text { Малі } \\
\text { підпр. }\end{array}$ & $\begin{array}{c}\text { Се- } \\
\text { редні } \\
\text { підпр. }\end{array}$ & $\begin{array}{c}\text { Великі } \\
\text { підпр. }\end{array}$ & $\begin{array}{c}\text { Частка під- } \\
\text { що подаютв, } \\
\text { нефінансову } \\
\text { звітність, } \%\end{array}$ \\
\hline 1 & Африка & 6 & 4 & 2 & 0 & 1 & 5 & 3 \\
\hline 2 & Азія & 61 & 38 & 23 & 13 & 13 & 35 & 32 \\
\hline 3 & Свропа & 41 & 30 & 11 & 16 & 7 & 18 & 22 \\
\hline 4 & $\begin{array}{l}\text { в т.ч. } \\
\text { Україна }\end{array}$ & 3 & 2 & 1 & 0 & 0 & 3 & 2 \\
\hline 5 & $\begin{array}{l}\text { Південна } \\
\text { Америка }\end{array}$ & 61 & 56 & 5 & 21 & 6 & 34 & 32 \\
\hline 6 & $\begin{array}{l}\text { Північна } \\
\text { Америка }\end{array}$ & 15 & 7 & 8 & 4 & 7 & 4 & 8 \\
\hline 7 & Океанія & 6 & 4 & 2 & 3 & 0 & 3 & 3 \\
\hline & Загалом & 190 & 139 & 51 & 57 & 34 & 99 & 100 \\
\hline
\end{tabular}

Джерело: розроблено автором за даними [4] 
За даними табл. 1 сільськогосподарські підприємства Євразії (54\%) та Південної Америки (32\%) є найбільшими продуцентами нефінансових звітів у 2016 році, що пояснюється концентрацією сільського господарства в цих регіонах. Що стосується розподілу товаровиробників за розміром підприємства, то великі та середні підприємства - це у більшості концерни та агрохолдинги, що є найбільшими землевласниками із загальним земельним банком від 50 тис. га оброблюваної площі, а малі підприємства - це не окремі господарства, а кооперативи або союзи кооперативів.

Для України, так і для всього світу, є актуальним питання щодо розроблення концепції обліково-аналітичного підходу до формування звітності про сталий розвиток на засадах корпоративної соціальної відповідальності. Серед 100 найбільших українських землевласників (15-605 тис. га) тільки три формують і публікують нефінансову звітність про сталий розвиток, що складає 14\% від загальної кількості підприємств у економіці - емітентів звітності про сталий розвиток: це вертикальноінтегрований агропромисловий холдинг “Астарта”, найбільший агрохолдинг України “Кернел” та публічне акціонерне товариство "Миронівський хлібопродукт".

Українські сільгоспвиробники не усвідомлюють мету формування та представлення нефінансової інформації, а іноді не в змозі ії відобразити через такі причини:

1) брак досліджень в галузі сталого розвитку в цілому і звітності зокрема;

2) зосередження уваги дослідників і зацікавлених осіб на вирішенні питань представлення нефінансової інформації тільки на великих підприємствах;

3) обмеженість концептуальних основ звітності з обліку сталого розвитку сільського господарства, що звужує характеристики бухгалтерського обліку в розрізі принципів, процедур, звітів, переваг, показників сталого розвитку;

4) нехтування соціальними та екологічними умовами господарювання і зосередження на економічних результатах;

5) ізольованість аналізу ключових факторів успіху для формування конкурентних переваг;

6) недостатній рівень кваліфікації кадрів для формування звітів про сталий розвиток.

Турбулентна сучасність очевидно диктує нові правила конкурентної боротьби сільськогосподарським підприємствам, коли не якість товару, а репутація суб'єкта господарювання становить дедалі більшу частку ринкової капіталізації. Можна казати про те, що підвищення інвестиційної привабливості є фактором збереження акціонерного капіталу. Призначення звітності про сталий розвиток полягає у доведенні до зацікавлених сторін прагнення підприємства відповідати показникам продуктивності й очікуванням зацікавлених сторін щодо фінансових, екологічних та соціальних питань. Крім того, шляхом інтеграції показників сталого розвитку в процеси управління компанія може визначити нові зв'язки між змінами продуктивності та факторами, що формують вартість акціонерного капіталу.

На думку деяких українських вчених, результати вивчення впливу різних положень стандартів сталого розвитку на вітчизняну систему звітності про сталий розвиток свідчать, що підготовлена за стандартами звітність не завжди повністю відповідає стандартам, а окремі підприємства навіть іiі не верифікують, що значно знижує іiі інформаційну наповненість та задоволеність зовнішніх і внутрішніх користувачів [5, с. 313]. Такий стан речей зумовлений відсутністю належного методичного та обліково-аналітичного забезпечення звітності про сталий розвиток сільськогосподарських підприємств.

О. А. Романенко вказує на вагання підприємств стосовно звітності про сталий розвиток, яка робить підприємство прозорим, а відтак відкритим для більшої критики [6, с. 882]. Однак ми вважаємо, що відсутність прозорості більшою мірою загрожує підприємствам втратою довіри з боку зацікавлених сторін (стейкхолдерів), ніж їх критика.

В Україні стейкхолдерами пропонують вважати акціонерів, співробітників, партнерів, клієнтів і все суспільство [7], тобто всіх зацікавлених осіб, які приймають рішення щодо взаємодії з об'єктом формування нефінансової звітності.

Оскільки відповідальне ставлення підприємств, організацій та установ до своїх обов' язків перед зацікавленими сторонами називають як соціальною, так і корпоратив- 
ною відповідальністю, застосування терміна “звіт із соціальної відповідальності” чи "звіт із корпоративної відповідальності” для позначення всієї сукупності таких звітів $\epsilon$ некоректним. Зустрічається таке об'єднане поняття як корпоративна соціальна відповідальність, що означає "раціональний відгук організації на систему суперечливих очікувань зацікавлених сторін (стейкхолдерів), який спрямований на стійкий розвиток компаній” [8, с. 6]. У зарубіжній та вітчизняній практиці найчастіше використовують термін “нефінансовий звіт”. С. Король віддає перевагу назві “нефінансовий звіт” для звітів із корпоративної соціальної відповідальності бізнесу, що пов’язано з відображенням інформаційного зв'язку таких звітів із фінансовими звітами та врахуванням їх місця у системі звітності підприємства i, нарешті, лаконічністю [3, с. 104]. Надалі ми у дослідженні ототожнюватимемо поняття “нефінансовий звіт” (нефінансова звітність) i “звіт про сталий розвиток” (звітність про сталий розвиток).

За допомогою герменевтичного методу дослідження поняття звітності про сталий розвиток та його альтернатив (нефінансова звітність $[9$, с. $31 ; 10$, с. 51], соціальна звітність $[11$, с. $6 ; 12$, с. 16; 13, с. 223], корпоративна соціальна звітність [14, с. 68-69]) нами запропоновано три варіанти звітів про сталий розвиток сільськогосподарського підприємства:

1. “Звіт про сталий розвиток сільськогосподарського підприємства”, що є додатком до фінансового звіту та характеризується підготовкою окремого звіту за вибраною та загальноприйнятою системою чи стандартом. Головною метою такого звіту є задоволення потреб в інформації стейкхолдерів великих сільськогосподарських підприємств для оцінки вже прийнятих і майбутніх рішень.

2. “Альтернативний звіт про сталий розвиток” - це окремий чи стислий звіт про сталий розвиток. Прикладом може бути екологічний звіт, соціальний звіт, звіт про корпоративну відповідальність, звіт про корпоративну соціальну відповідальність і т. д.). Кожен з них пов'язаний із конкретною проблемою корпоративної стійкості і задовольняє інформаційні потреби різних груп зацікавлених сторін. Структура або вигляд звіту може змінюватись кожний період залежно від потреб користувачів інформації. Такі звіти складають насамперед середні сільськогосподарські підприємства.

3. "Розширений фінансовий звіт" $є$ таксономією фінансової звітності [15] або розширенням звичайної фінансово-економічної інформації через включення соціальних і екологічних результатів діяльності малих і мікросільськогосподарських підприємств. Цей вид звітності є найкращою альтернативою комплексній фінансовій звітності про сталий розвиток. Найкращим варіантом є включення аспектів сталого розвитку до звіту про фінансовий стан (баланс) та звіту про сукупний доход (звіту про фінансові результати).

Із року в рік зростає кількість компаній, що випускають звіт про сталий розвиток. Підприємства повинні постійно шукати довершений формат звітності для комунікації зі стейкхолдерами, що також відповідає їх власним цілям. Наслідком подібних експериментів $€$ поступова зміна змісту і формату звітності про сталий розвиток водночас із розробленням ії нових форм.

Сільськогосподарські підприємства беруть участь у сфері сталого розвитку, навіть не усвідомлюючи цього. Економічне обгрунтування використання принципів сталого розвитку окремими сільськогосподарськими підприємствами має спонукати інші підприємства до переходу на формування звітності за принципами сталого розвитку. Світові дослідження доводять: в компаніях, що впроваджують звітність про сталий розвиток, доходність продажів зростає на $3 \%$, активів - на $4 \%$, а капіталу та акцій - більш ніж на 10\% [16].

Сільськогосподарські підприємства, орієнтовані на довгострокову перспективу, у такий спосіб переслідують особистий інтерес, стаючи рушійною силою суспільства до сталого розвитку. У доповіді “Економічне обгрунтування для сталого розвитку” Всесвітньої ради підприємців зі сталого розвитку (World Business Council For Sustainable Development, WBCSD) [17, с. 229] йшлося про десять блоків для побудови суспільства за принципами сталого розвитку. Деякі з них вже використовуються сільськогосподарськими підприємствами, наприклад ринкова конкуренція, інновації, еко-ефективність, діалог і партнерські відносини. Запровадження інших, таких як вектор розвитку, корпоративна соціальна відповідальність, прогнозування та своєчасне реагування на 
зміни, надання вибору споживачам, збереження природно-ресурсного потенціалу та його інвестиційної привабливості, $є$ більш складною задачею для агробізнесу та його стейкхолдерів.

Аналіз десяти вимірників бізнес-успіху та десяти характеристик сталого розвитку сільськогосподарського підприємства [18] $є$ підгрунтям для розроблення автором матриці оцінки рівня обліково-аналітичного забезпечення сталого розвитку сільськогосподарського підприємства (рис. 1).

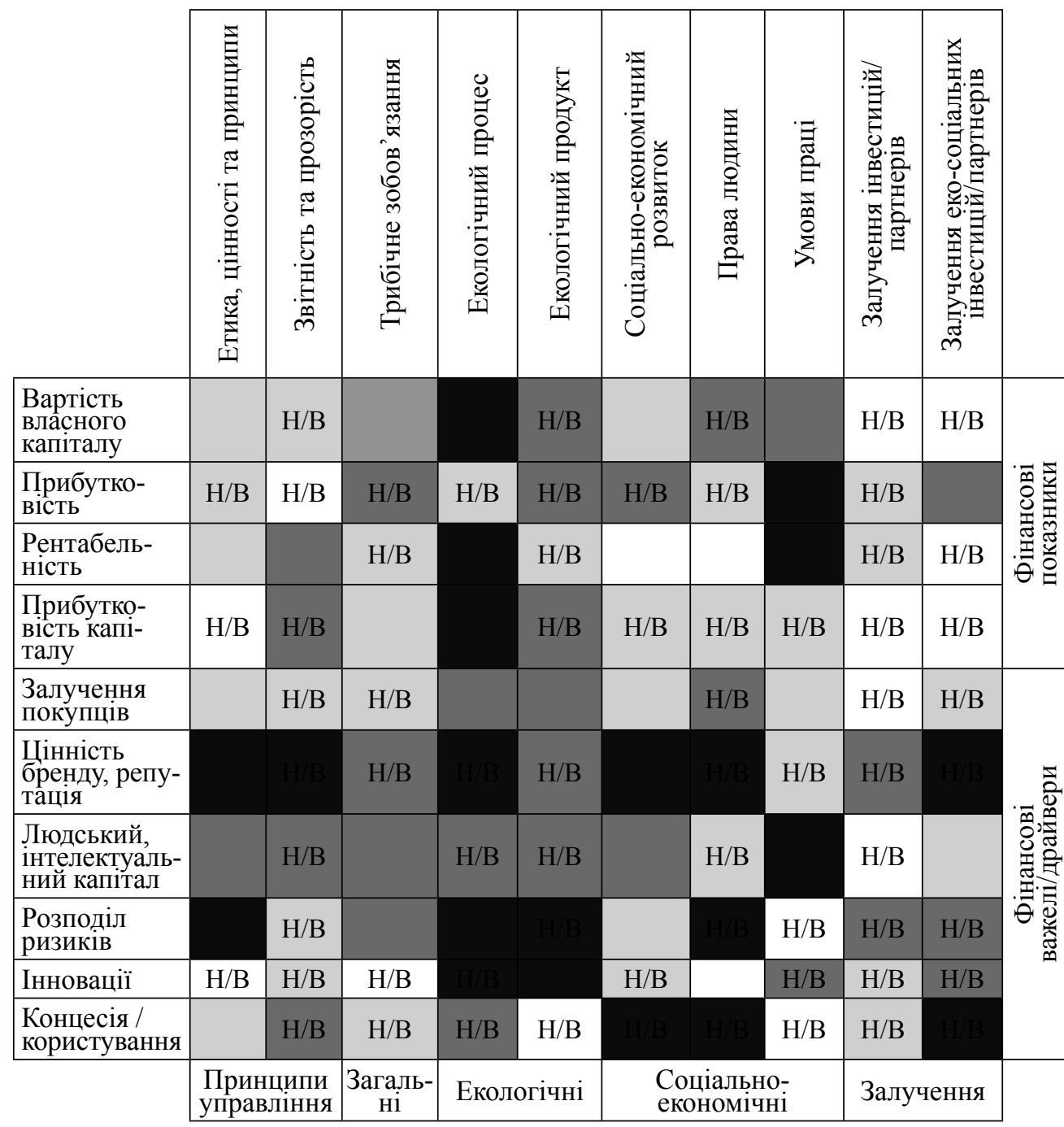

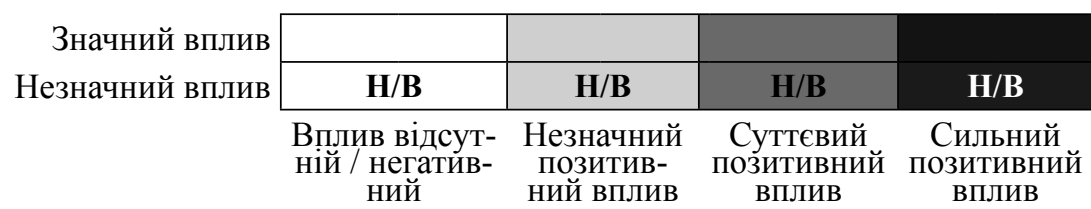

Рис. 1. Матриця оцінки рівня обліково-аналітичного забезпечення сталого розвитку сільськогосподарського підприємства

Джерело: розроблено автором з використанням даних [18]

Матриця (рис. 1) ілюструє вплив аспектів сталого розвитку (сильний, суттєвий, незначний, відсутній) на рівень обліково-аналітичного забезпечення процесу формування фінансових результатів та їх відображення у звітності про сталий розвиток. Матриця 
пов'язує десять показників ефективності сталого розвитку з десятьма традиційними заходами успіху в бізнесі, що може бути використано сільськогосподарськими підприємствами при оцінці їх індивідуального бізнес-обгрунтування сталого розвитку. Крім того, сільськогосподарським підприємствам для формування обліковоаналітичного забезпечення звітності про сталий розвиток необхідно визначитись із доцільністю формування еко-соціальних та економічних результатів (рис. 2).

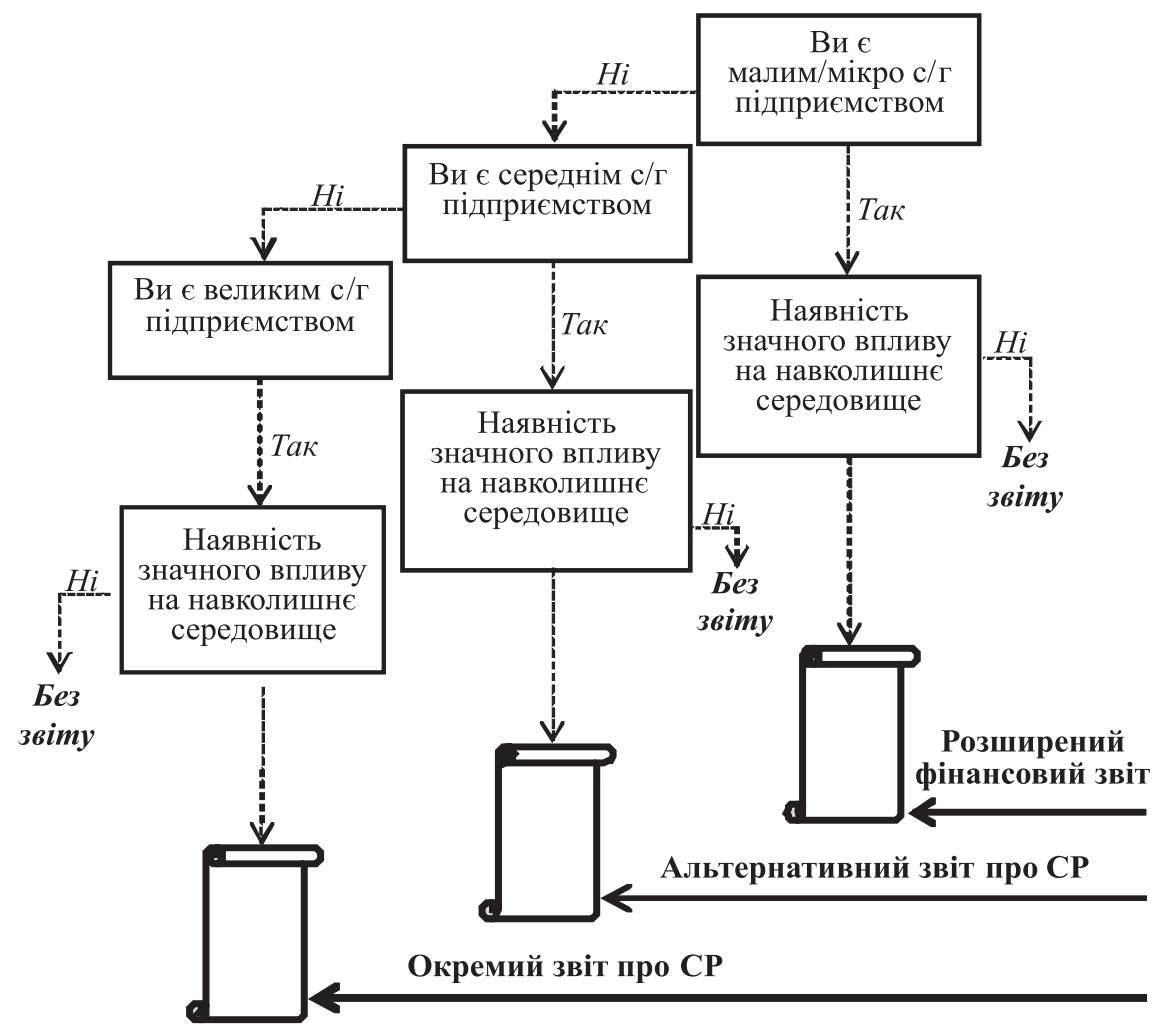

Рис. 2. Дерево рішень для визначення варіантів звітності
про сталий розвиток сільськогосподарських підприсмств

Джерело: розроблено автором

Для прийняття рішення сільськогосподарським підприємством щодо формування звітності за принципами сталого розвитку можна користуватися матрицею (рис. 1) або деревом рішень (рис. 2). Крім того, визначальним моментом у переході аграрних підприємств до “звіту про управління, що містить фінансову та нефінансову інформацію" є зміни до Закону України "Про бухгалтерський облік та фінансову звітність в Україні” [16]. Дотримання цієї процедури вимагає від сільськогосподарського підприємства володіння не тільки загальними принципами формування звітності, а й методикою складання звітності про сталий розвиток. В деяких ситуаціях необхідна експертна підтримка. За даними консалтингової компанії BakerTilly, в Україні станом на 2017 рік існують лише чотири сертифіковані програми підготовки фахівців із формування й подання звітності в сфері сталого розвитку [2].

Проте оцінка сільськогосподарськими підприємствами своїх можливостей може дезорієнтувати та ускладнити використання дерева рішень, однак у всіх випадках, незалежно від розміру підприємства, відбувається взаємодія із зовнішнім середовищем, а відтак і вплив на нього. Тому альтернатива відповіді “Ні” на питання про вплив повинна нівелюватися зі збільшенням розміру сільськогосподарського підприємства. Потужні агрохолдинги мають потенційно більший вплив на зовнішнє середовище, ніж індивідуальний фермер, внаслідок чого посилюється їх відповідальність та збільшується кількість альтернативних варіантів звітності про сталий розвиток. 
Висновки та перспективи досліджень. Звітність про сталий розвиток сільськогосподарського підприємства як систему формування інформації можливо складати за трьома варіантами залежно від розміру підприємства. Згідно з останніми змінами Закону України "Про бухгалтерський облік і фінансову звітність в Україні" всі без винятку підприємства мають право на формування нефінансових звітів - “звітів про управління”, а великі та підприємства, що становлять суспільний інтерес, зобов'язані це робити. Задля підвищення іміджу або інвестиційної привабливості сільськогосподарські підприємства мають переходити до сучасних методів формування звітності про результати економічної, екологічної та соціальної діяльності.

Перспективи подальших розвідок у цьому напряму будуть присвячені стандартизації та розробленню методики обліково-аналітичного забезпечення формування звітності сільськогосподарських підприємств про сталий розвиток за їх розміром та спеціалізацією.

\section{Список використаних джерел}

1. Ballou B., Heitger D., Landes C. The Future of Corporate Sustainability Reporting, A Rapidly Growing Assurance Opportunity // Journal of Accountancy. 2006. No 12. P. 1-9.

2. Нефінансова звітність за стандартом GRI у світі та Україні. Офіційний сайт компанії Baker Tilly. Електронний ресурс. URL: http://www.bakertilly.ua/news/id1129. (Дата звернення 03.12.2017)

3. Король С. Нефінансова звітність підприємства // Вісник Київського національного торговельно-економічного університету. 2011. № 6. С. 102-113.

4. Глобальна ініціатива зі звітності (Global Reporting Initiative) [Електронний ресурс]. URL: http://database.globalreporting.org/ (Дата звернення: 04.12.2017)

5. Свірко С. В., Баришнікова О. М. Звітність сталого розвитку як засіб відображення стану економіко-екологічної безпеки підприємства // Проблеми теорії та методології бухгалтерського обліку, контролю і аналізу. 2015. № 3(33). С. 309-325.

6. Романенко О. А., Комірна О. В. Аналіз інтегрованої звітності у забезпеченні сталого розвитку суспільства // Глобальні та національні проблеми економіки. Електронне наукове фахове видання. 2017. Вип. 17. С. 880-887.

7. Мацьків Р. Т. Нефінансова звітність - складова управління соціальною відповідальністю підприємств нафтогазового комплексу [Електронний ресурс] // Ефективна економіка. 2015. № 3. URL: http://www.economy.nayka.com.ua/?op=1\&z=3926 (Дата звернення 04.12.2017)

8. Колот А. М. Корпоративна соціальна відповідальність: еволюція та розвиток теоретичних поглядів // Економічна теорія. 2013. № 4. С. 5-26.

9. Гриценко О. І. Тенденції та проблеми формування інтегрованої звітності суб'єктами господарювання // Молодий вчений. 2014. № 2(05). С. 31-34.

10. Довга Т. Формування екологічної звітності сміттєпереробних підприємств // Вісник КНУ імені Тараса Шевченка. 2012. № 143. С. 50-53.

11. Воробей В., Журовська І. Нефінансова звітність: інструмент соціально відповідального бізнесу. К.: Представництво ООН в Україні, 2010. 84 с.

12. Сингаївська А. М. Корпоративна соціальна відповідальність: опорний конспект. К.: Київський університет ринкових відносин, 2013. 41 с.

13. Хамідова О. М., Хамідова А. Ш. Складання соціальної звітності як важливий етап реалізації соціально-відповідального маркетингу підприємства галузі мінеральних добрив // Экономика Крыма. 2010. № 2(31). С. 222-226.

14. Лазоренко О., Колишко Р. та ін. Посібник із КСВ. Базова інформація з корпоративної соціальної відповідальності. К.: Видавництво “Енергія”, 2008. 96 с.

15. Закон України "Про внесення змін до Закону України "Про бухгалтерський облік та фінансову звітність в Україні” щодо удосконалення деяких положень” від 5 жовтня 2017 року № 2164-VIII // Відомості Верховної Ради (ВВР), 2017, № 44, ст. 397.

16. ЕY: компанії ризикують втратити інвестиції через відсутність нефінансової інформації [Електронний ресурc]. URL: http://csr-ukraine.org/news/еу-компаніїризикують-втратити-інвести/. Заголовок з екрану. (Дата звернення: 05.12.2017) 
17. WBCSD. The Business Case for Sustainable Development: Making a Difference towards the Earth Summit 2002 and Beyond // Corporate Environmental Strategy. 2002. No 9. Vol. 3. P. 226-235.

18. Buried Treasure. Uncovering the business case for corporate sustainability. First Edition. SustainAbility. 2001. 62 p.

\section{References}

1. Ballou B., Heitger D., Landes C. (2006). The Future of Corporate Sustainability Reporting, A Rapidly Growing Assurance Opportunity. Journal of Accountancy, 12, $1-9$.

2. Nefinansova zvitnist za standartom GRI u sviti ta Ukraini. Ofitsiinyi sait kompanii Baker Tilly [Non-financial reporting by GRI standard in the world and in Ukraine]. Retrieved from http://www.bakertilly.ua/news/id1 129. (Data zvernennia 03.12.2017) [in Ukrainian].

3. Korol S. (2011). Nefinansova zvitnist pidpryiemstva [Non-financial reporting of an enterprise]. Visnyk Kyivskoho natsionalnoho torhovelno-ekonomichnoho universytetu Bulletin of Kyiv National University of Trade and Economics, 6, 102-113 [in Ukrainian].

4. Global Reporting Initiative. Retrieved from http://database.globalreporting.org/ (Date of access 04.12.2017) [in Ukrainain].

5. Svirko S. V., Baryshnikova O. M. (2015). Zvitnist staloho rozvytku yak zasib vidobrazhennia stanu ekonomiko-ekolohichnoi bezpeky pidpryiemstva [Sustainable development reporting: a means for recording the economic and ecological safety of an enterprise]. Problemy teorii ta metodolohii bukhhalterskoho obliku, kontroliu i analizuProblems of theory and methodology of accounting, control and analysis, 3(33), 309-325 [in Ukrainian].

6. Romanenko O. A., Komirna O. V. (2017). Analiz intehrovanoi zvitnosti u zabezpechenni staloho rozvytku suspilstva [Analysis of integrated reporting: a means to ensure the sustainable development of the society]. Hlobalni ta natsionalni problemy ekonomiky. Elektronne naukove fakhove vydannia - Global and national problems of economics. An electronic professional journal, 17, 880-887 [in Ukrainian].

7. Matskiv R. T. (2015). Nefinansova zvitnist - skladova upravlinnia sotsialnoiu vidpovidalnistiu pidpryiemstv naftohazovoho kompleksu [Non-financial reporting - a component in the social responsibility management of the oil and gas complex]. Efektyvna ekonomika - The effective economy, 3. Retrieved from http://www.economy.nayka.com. $\mathrm{ua} / ? \mathrm{op}=1 \& \mathrm{z}=3926$ (Date of access 04.12.2017) [in Ukrainian].

8. Kolot A. M. (2013). Korporatyvna sotsialna vidpovidalnist: evoliutsiia ta rozvytok teoretychnykh pohliadiv [The corporate social responsibility: evolution and development of theoretical views]. Ekonomichna teoriia - Economic theory, 4, 5-26 [in Ukrainian].

9. Hrytsenko O. I. (2014). Tendentsii ta problemy formuvannia intehrovanoi zvitnosti subiektamy hospodariuvannia [Forming the integrated reporting by business entities: tendencies and problems]. Molodyi vchenyi-Young scientist, 2(05), 31-34 [in Ukrainian].

10. Dovha T. (2012). Formuvannia ekolohichnoi zvitnosti smittiepererobnykh pidpryiemstv [Forming the ecological reporting by waste recycling enterprises]. Visnyk KNU imeni Tarasa Shevchenka - Bulletin of Kyiv National Taras Shevchenko University, 143, 50-53 [in Ukrainian].

11. Vorobei V., Zhurovska I. (2010). Nefinansova zvitnist: instrument sotsialno vidpovidalnoho biznesu [Non-financial reporting: an instrument for socially responsible business]. Kyiv: UN Office in Ukraine [in Ukrainian].

12. Synhaivska A. M. (2013). Korporatyvna sotsialna vidpovidalnist: opornyi konspekt [The corporate social responsibility: a compendium]. Kyiv: Kyiv University of Market Relations [in Ukrainian].

13. Khamidova O. M., Khamidova A. Sh. (2010). Skladannia sotsialnoi zvitnosti yak vazhlyvyi etap realizatsii sotsialno-vidpovidalnoho marketynhu pidpryiemstva haluzi mineralnykh dobryv [Making up social reporting: an important phase in implementing socially responsible marketing of an enterprise in the mineral fertilizers industry]. Ekonomika Kryma - The economy of Crimea, 2(31), 222-226 [in Ukrainian].

14. Lazorenko O., Kolyshko R. et al. (2008). Posibnyk iz KSV. Bazova informatsiia z korporatyvnoi sotsialnoi vidpovidalnosti [Manual on KSV. Essentials on the corporate social responsibility]. Kyiv: Vydavnytstvo "Enerhiia" [in Ukrainian]. 
15. Zakon Ukrainy "Pro vnesennia zmin do Zakonu Ukrainy "Pro bukhhalterskyi oblik ta finansovu zvitnist v Ukraini" shchodo udoskonalennia deiakykh polozhen" vid 5 zhovtnia 2017 roku № 2164-VIII [The Law of Ukraine "Amendments to the Law of Ukraine 'Accounting and financial reporting in Ukraine', to improve some provisions" from 5 October 2017 No 2164-VIII]. Vidomosti Verkhovnoi Rady - Bulletin of the Verkhovna Rada, 2017, No 44, art. 397 [in Ukrainian].

16. EY: kompanii ryzykuiut vtratyty investytsii cherez vidsutnist nefinansovoi informatsii [EY: companies risk losing investment due to the absence of non-financial information]. Retrieved from http://csr-ukraine.org/news/ey-kompanii-ryzykuiut-vtratyty-investy/. Zaholovok z ekranu. (Date of access: 05.12.2017) [in Ukrainian].

17. WBCSD. The Business Case for Sustainable Development: Making a Difference towards the Earth Summit 2002 and Beyond (2002). Corporate Environmental Strategy, 9(3), 226-235.

18. Buried Treasure. Uncovering the business case for corporate sustainability. First Edition. SustainAbility. 2001.

\section{О. Г. СОКОЛ, \\ кандидат экономических наук, дочент кафедры учета и налогообложения, Таврический государственный агротехнологический университет \\ Методологическая основа учетно-аналитического обеспечения формирования отчетности об устойчивом развитии сельскохозяйственных предприятий}

В статье проанализированы мировые тенденции подготовки отчетности по корпоративной ответственности сельскохозяйственными предприятиями. Предложены три варианта отчетов об устойчивом развитии сельскохозяйственного предприятия: отчет об устойчивом развитии; альтернативный отчет; расширенный финансовый отчет. Разработана матрица оценки уровня учетно-аналитического обеспечения устойчивого развития сельскохозяйственного предприятия, которая иллюстрирует влияние (сильное, существенное, незначительное, отсутствует) десяти аспектов устойчивого развития на уровень учетно-аналитического обеспечения прочесса формирования финансовых результатов и их отражение в отчетности об устойчивом развитии. Построено дерево решений для определения вариантов отчетности об устойчивом развитии в зависимости от величинь сельскохозяйственных предприятий, их самоидентификации и осознании влияния на эко-социальную среду.

Ключевые слова: учетно-аналитическое обеспечение, отчетность об устойчивом развитии, отчет об устойчивом развитии, сельскохозяйственное предприятие, нефинансовой отчетности, заинтересованные стороны.

O. H. SOKIL, PhD (Economics), Associate Professor of Accounting and Taxation Department, Tavria State Agrotechnological University

\section{Sustainable Development Reports of Agricultural Enterprises: The Methodological Framework for Accounting and Analytical Support}

The research problem of accounting and analytical support for the formation of sustainable development reports by agricultural enterprises is characterized by many important aspects related specifically to accounting, analysis, reporting and standardization. In addition, there is a need to develop a methodological framework for reporting on sustainable development in agricultural sector despite previous fundamental research and synthesis of previous aspects of sustainable development reporting. 
The purpose of the article is to generalize the theoretical aspects and develop a methodological framework for accounting and analytical support for the formation of sustainable development reports by agricultural enterprises.

The global trend in reporting on corporate responsibility by agricultural enterprises is analyzed in the article. It is established that agricultural enterprises in Eurasia and South America were the largest producers of non-financial reports in 2016, which can be explained by the concentration of agriculture in these regions. Of the Ukrainian agricultural enterprises, non-financial reports have been prepared by only three agroconcerns. The main reasons discouraging Ukrainian agricultural producers from making and releasing sustainable development reports are highlighted. Using the hermeneutic method to analyze the sustainable development reporting definition and its alternatives, three options of sustainable development reports of an enterprise are proposed: a report on sustainable development; an alternative report; and an expanded financial report.

A matrix for assessing the level of accounting and analytical support for sustainable development of agricultural enterprises has been developed, illustrating the impact of ten sustainable development aspects (strong, essential, insignificant, none) on the accounting and analytical support for the process of generating financial results and their recording in sustainable development reports. A decision tree is built for selecting the options of sustainable development reporting by size of agricultural enterprise, its self-identification and awareness of the impact on the eco-social environment.

Keywords: accounting and analytical support, sustainable development reporting, sustainable development reports, agricultural enterprise, non-financial reporting, stakeholders.

\section{Посилання на статтю:}

Сокіл О. Г. Методологічна основа обліково-аналітичного забезпечення формування звітності сільськогосподарських підприємств про сталий розвиток // Науковий вісник Національної академії статистики, обліку та аудиту: зб. наук. пр. 2018. №1-2. C. 47-56. 